\title{
PERMASALAHAN PROSES PEMBELAJARAN PADA ANAK BERKEBUTUHAN KHUSUS HIPERAKTIF DI SEKOLAH LUAR BIASA NEGERI MARTAPURA KABUPATEN OKU TIMUR
}

\author{
Lisa Roniyati ${ }^{1}$, Ratih Purnama pertiwi ${ }^{2}$ \\ 15.86232 .034 \\ Pendidikan Guru Madrasah Ibtidaiyah \\ STKIP Nurul Huda Sukaraja Oku Timur \\ E-mail: lisaroniyaati@gmail.com
}

\begin{abstract}
ABSTRAK
Latar belakang penelitian ini adalah pentingnya mengetahui permasalahan proses pembelajaran anak hiperaktif dan bagaimana cara penanganan yang dilakukan oleh guru. Karena setiap anak pasti menggalami banyak permasalahan pembelajaran tidak hanya anak normal namun anak berkebutuhan khusus sangat rentang dalam permasalahan yang mereka hadapi pada proses pembelajaran. Salah satunya yaitu di SLB Negeri Martapura kabupaten OKU TIMUR. Telah diketahui beberapa cara yang dilakukan guru untuk mengatasi permasalahan proses pembelajaran pada anak hiperaktif, yaitu dengan menggunakan pendekatan, metode dan media yang menggunakan benda konkrit.

Subjek penelitian ini adalah guru kelas, guru khusus, orang tua dan kepalas sekolah untuk mengetahui permasalahn proses pembelajaran pada anak berkebutuhan khusus hiperaktif di SLB Negeri Martapura Kabupaten OKU TIMUR. Penelitian ini merupakan penelitian deskriptif dengan pendekatan kualitatif, penelitian bertujuan untuk mendeskripsikan permasalahan proses pembelajaran anak berkebutuhan khusus hiperaktif.

Pengumpulan data dilaksanakan melalui observasi berperan serta, wawancara mendalam, dan studi dokumen. Analisis data dilakukan dengan cara memberikan beberapa pertanyaan dan merangkum analisis data yang diperoleh. Pemeriksaan keabsahan data dilakukan dengan menggunakan teknik triangulasi, yaitu triangulasi sumber. Hasil penelitian menunjukan bahwa permasalahan yang dialami anak hiperaktif adalah konsentrasi, ketenangan siswa dan emosional siswa yang sulit terkontrol. Maka diperlukan nya pendekatan yang lebih dilakukan oleh guru khusus dan guru kelas. Dari 4 siswa semua menjadi subjek penelitian.
\end{abstract}

Kata kunci: permasalahan proses pembelajaran anak berkebutuhan khusus hiperaktif

\section{PENDAHULUAN}

Pendidikan adalah usaha sadar dan terencana untuk mewujudkan suasana belajar dan proses pembelajaran untuk peserta didik agar secara aktif mengembangkan potensi dirinya untuk memiliki kekuatan spiritual keagamaan, pengendalian diri, kepribadian, kecerdasan, ahlak mulia, serta keterampilan yang diperlukan dirinya dan masyarakat. Sesuai dengan UU Nomor 20 tahun 2003 tentang Sistem Pendidikan Nasional memberikan warna lain dalam penyediaan pendidikan bagi anak berkebutuhan khusus. Pada penjelasan pasal 15 tentang pendidikan khusus atau peserta didik yang memiliki kecerdasan luar biasa yang diselenggarakan secara inklusif dasar dan menengah. Pasal inilah yang memungkinkan bentuk pelayanan pendidikan bagi anak berkebutuhan khusus berupa penyelenggaraan pendidikan inklusif, secara lebih operasional, hal ini diperkuat dengan peraturan pemerintah Nomor 17 Tahun 2010 tentang pendidikan khusus dan pendidikan layanan khusus ( Jati Rinakri Atmaja,2017:3).

Anak berkebutuhan khusus (Heward) adalah anak dengan karakteristik khusus yang berbeda dengan anak pada umumnya tanpa selalu menunjukan pada ketidakmampuan mental, emosi atau fisik. Anak dengan karakteristik khusus yang berbeda dengan anak pada umumnya tanpa selalu menunjukan pada ketidak mampuan mental, emosi atau fisik. Yang termasuk kedalam ABK antara lain: tunanetra,tunarungu, tunagrahita,tunadaksa, tunalaras, kesulitan belajar, gangguan prilaku, anak berbakat, anak dengan gangguan kesehatan.

Istilah anak berkebutuhan khusus merupakan istilah terbaru yang digunakan, dan merupakan terjemahan dari child with special needs yang telah digunakan secara luas di dunia internasional, ada beberapa istilah lain yang pernah digunakan, diantaranya anak cacat, anak tuna, anak berkelainan, anak menyimpang, dan anak luar biasa. Ada satu istilah yang berkembang secara luas telah digunakan, yaitu difabel, sebenarnya merupakan 
kependekan dari difference ability. ( Jati Rinakri Atmaja, 2017:5)

Berdasarkan beberapa pendapat diatas dapat disimpulkan bahwa, Anak Berkebutuhan Khusus yaitu terjemahan dari child with special needs yang telah digunakan secara luas di dunia internasional, dan ada beberapa istilah lain yang pernah digunakan antaranya anak cacat, anak berkelainan, anak tuna, anak menyimpang, dan anak luar biasa. Keragaman anak berkebuthan khusus terkadang menyulitkan guru dalam upaya menemukan kenali jenis dan pemberian layanan pendekatan yang sesuai. Maka guru harus memiliki pendekatan dan pemahaman mengenai anak berkebutuhan khusus agar dapat memenuhi kebutuhan anak yang sesuai dengan dirinya.

Istilah hiperaktivitas berasal dari dua kata, yaitu hyper berarti banyak, di atas, tinggi dan activity berarti keadaan yang selalu bergerak, mengadakan eksplorasi serta respon terhadap rangsangan dari luar. Dengan demikian istilah dari hiperaktivitas berarti aktifitas yang dimiliki sangat tinggi tidak bertujuan dan cenderung bersifat negatif.

Hiperaktif adalah anak yang mengalami gangguan pemusatan perhatian dengan hiperaktif (GPPH) atau attention deficit and hyperactivity disorder (ADHD). Menurut Dr. Seto Mulyadi istilah anak hiperaktif menunjukan adanya suatu pola perilaku ini ditandai dengan sikap tidak mau diam,tidak bisa berkonsentrasi dan bertindak sekehendak hatinya atau implusif.(Jati Rinakri Atmaja, 2017 :236)

Dari kedua pengertian diatas dapat di simpulkan bahwa Hiperaktif adalah gangguan pada tingkah laku yang ditandai dengan tingginya aktifitas yang tidak bertujuan dan bersifat negatif yang di sebabkan oleh disfungsi neurologia. Hiperaktif ini ditandai dengan gejala utama tidak mampu memusatkan perhatian dan konsentrasi belajar.

Saat ini banyak sekali permasalahan yang dialami oleh anak berkebutuhan khusus, khususnya hiperaktif dan autis dalam proses pembelajaran, Karena siswa hiperaktif cenderung memiliki permasalahan akademis, maka perlunya suatu penanganan dan bimbingan yang tepat harus dilakukan oleh guru khusus, dan peran orangtua dalam mengatasi hal tersebut khususnya disekolah. Salah satu sekolah tersebut adalah Sekolah Luar Biasa Negeri Martapura Kabupaten Oku Timur.

\section{METODE PENELITIAN}

Jenis penelitian ini merupakan penelitian kualitatif dengan jenis penelitian study kasus.yaitu penelitian yang digunakan untuk mendapatkan data dari tempat tertentu yang alamiah. Dalam objek penelitian adalah permasalahan pembelajaran siswa hiperaktif yang akan diteliti. Teknik pengumpulan data dalam penelitian ini menggunakan Observasi, wawancara dan Dokumentasi. Keabsahan data yang digunakan adalah triagulasi.

\section{HASIL PENELITIAN}

Penanganan yang lebih ditekan guru adalah permasalahan proses pembelajaran siswa hiperaktif, penangan yang benar-benar harus di perhatikan oleh guru adalah kebiasaan siswa dan masalah atau kendala yang dialami oleh siswa hiperaktif. Yang harus dilakukan guru adalah berupa pendekatan terlebih dahulu untuk mengenal karakter dan kebiasaan siswa hiperaktif sebelum melakukan kegiatan proses pembelajaran. Selain memberikan penanganan yang tepat terhadap siswa hiperaktif guru juga harus mempersiapkan bahan atau alat peraga untuk proses pembelajaran agar proses pembelajaran berjalan sesuai dengan kebutuhan siswa hiperaktif. 
Berdasarkan hasil wawancara yang peneliti lakukan kepada Guru kelas siswa hiperaktif di SLB Negeri Martapura saat ditanyakan mengenai adakah permasalahan proses pembelajaran siswa hiperaktif Guru kelas mengatakan:

“ Permasalah proses pembelajaran siswa hiperaktif adalah siswa tidak bisa diam dan tenang ketika pembelajaran berlangsung dan biasanya satu siswa hiperaktif di tangani oleh 2 guru khusus, selain itu guru harus memahami apa yang menjadi keinginan siswa saat proses pembelajaran.”(W/G1/Fa/04/09/2019)

Berdasarkan hasil wawancara di atas, dapat ditarik kesimpulan bahwa permasalahan proses pembelajaran siswa hiperaktif terletak pada kesiapkan dan ketenangan siswa itu sendiri ketika siswa akan melaksanakan pembelajaran di sekolah. Maka pemaparan hasil wawancara sesuai dengan pendapat yang sudah dijelaskan dalam pengertian pembelajaran itu sendiri yaitu pembelajaran merupakan susatu kegiatan atau proses yang sistematik yang bersifat interaktif yang di laksanakan oleh pendidik dan siswa, sumber belajar lain, dan lingkungan yang mampu menciptakan suatu kondisi yang memungkinkan untuk terjadinya proses pembelajaran siswa.

Sebagai seorang guru harus memiliki beberapa metode dan pendekatan yang digunakan untuk menangani permasalahan proses pembelajaran siswa hiperaktif. Maka diharapkan pendidik tetap mempertahankan berbagai macam metode dan pendekatan yang telah dilakukan sebelumnya, karena metode dan pendekatan tersebut telah memberikan motifasi siswa untuk tetap mau belajar selama proses pembelajaran berlangsung. Namun, akan lebih baik jika guru lebih mengembangkan metode baru yang dapat membuat siswa merasa lebih semangat dan termotivasi dalam melaksanakan proses pembelajaran. Cara tersebut dapat membuat siswa tidak merasa bosan dengan metode yang sesuai dengan kebutuhan siswa, seperti yang telah dijelas sesuai oleh guru dibawah ini.

"Selain penggunaan pedekatan diperlukan juga penggunaan metode pembelajaran yang tepat dan sesuai dengan kebutuhan siswa. Biasanya guru menggunakan metode pembelajaran secara bergantian agar siswa tidak merasa bosan dalam melaksanakan proses pembelajaran”. (W/G/F1.c/04/09/2019)

Berdasarkan pendapat diatas dapat disimpulkan bahwa metode pembelajaran adalah cara yang digunakan oleh pendidik untuk mencapai suatu tujuan tertentu. Agar tercapai nya pembelajaran yang efektif sehingga diperlukan nya suatu metode yang digunakan guru, sama halnya dengan proses pembelajaran yang di laksanakan oleh anak hiperaktif tetap harus menggunakan metode yang tepat dan sesuai dengan kebutuhan anak agar terciptanya suatu proses pembelajaran yang menyenangkan dan siswa mudah menerima materi yang telah disampaikan oleh guru.

\section{a.Faktor Penyebab Anak Hiperaktif}

Beberapa faktor yang dapat menyebabkan anak mengalami gangguan hiperaktif. Namun terkadang sebagai orang tua tidak dapat menyadari faktor penyebab yang membuat anak mengalami hiperaktif. Seperti penyataan yang telah disampaikan oleh guru khusus siswa hiperaktif, mengatakan bahwa :

"Ada beberapa faktor yang dapat menyebabkan anak hiperaktif yaitu : adanya faktor keturunan dari keluarga yang telah mengalami gangguan hiperaktif terlebih dahulu, kurangnya perhatiaan dari lingkungan baik lingkungan keluarga mau pun lingkungan masyrakat, kurangnya gizi pada saat dikandungan yang dapat menyebabkan penurunan berat badan pada ibu saat masa kehamilan, dan kelahiran anak yang prematur".(W/G1/F.c/04/09/2019)

Berdasarkan beberapa pendapat yang telah disampaikan diatas maka dapat di simpulkan bahwa, sebaiknya sebagai orang tua harus sangat berhati-hati menjaga kondisi kesehatan pada saat masa kehamilan, memberikan asupan gizi yang sesuai dengan kebutuhan anak agar tetap terjaga kondisi berat badan, memberikan permainan yang sesuai dengan usia anak dan sebaiknya anak lebih diawasi lagi dalam berinteraksi dilingkungan masyarakat. Dan untuk mengurangi resiko gangguan hiperaktif yang diakibatkan karena faktor keturunan yang akan terjadi pada anak hiperaktif sebaiknya di lakukan terapi dan cek kondisi kesehatan secara rutin.

\section{b. Pengunaan Media yang Tepat}

Media yang digunakan oleh guru sebaiknya lebih menarik, mudah dipahami oleh siswa, dan sesuai dengan kebutuhan siswa hiperaktif. Namun, jika pendidik tidak menggunakan media yang tepat dan sesuai dengan kebutuhan anak maka siswa akan sangat sulit untuk memahami materi yang disampaikan oleh guru.

Bedasarkan hasil wawancara dengan Guru kelas hiperaktif yang menyatakan bahwa:

"selain metode dan pendekatan yang di gunakan guru terhadap siswa hiperaktif, Guru juga menggunakan beberapa media yang menarik untuk siswa seperti media dengan benda konkret atau gambar yang terlihat nyata, Seperti mengenal warna nama-nama hewan maka guru akan menggunakan media benda yang menyerupai hewan-hewan tersebut. Ketika mengenal warna maka guru akan menggunakan media puzzel agar siswa tidak merasa bosan, Namun ketika siswa hiperaktif belajar mengenal satu nama hewan saja prosesnya sangatlah lama harus berulang-ulang kali untuk mengingatkan peserta didik. Karena anak hiperaktif cenderung sulit menghafal dalam waktu singkat".(W/G2/F1.c/04/09/2019)

Strategi pembelajaran yang digunakan guru adalah dengan menggunakan metode, pendekatan dan media yang tepat maka akan membuat siswa lebih tenang dalam melaksakan proses pembelajaran. Selain itu dengan dengan menggunakan metode,media dan pendekatan guru juga harus memiliki beberapa cara untuk menenangkan siswa dengan cara mengenali dunia yang di miliki siswa karena siswa hiperaktif itu cenderung 
memiliki dunia nya sendiri. Pendekatan yang dilakukan guru berupaya untuk agar siswa mampu mengontrol emosi dan ketenangan mereka sendiri, karena siswa hiperaktif dikenal dengan siswa yang tidak bisa tenang dalam menghadapi situasi apa pun, memiliki tingkat emosi yang tinggi sehingga apa pun yang ada di depan meraka akan di lempar ketika mereka merasa tidak nyaman.

Bedasarkan wawancara yang dilakukan kepada guru kelas hiperaktif yaitu:

"Penggunaan media juga sangat diperlukan untuk menarik minat berlahar siswa, dan memfokuskan siswa pada materi yang disampaikan oleh guru. Media yang digunkan adalah media benda kongkrit atau media gambar. Karena siswa hiperaktif cenderung sulit untuk memahami materi yanag diberikan guru, maka diperlukan nya ketelatenan serta kesabaran lebih dalam menghadapi siswa hiperaktif" (W/G/F1.d/05/09/2019).

Bedasarkan pemaparan di atas yang telah dijelaskan oleh guru kelas hiperaktif, media pembelajaran adalah semua alat atau benda yang digunakan untuk kegiataan pembelajaran dengan maksut menyampaikan pesan atau informasi yang digunakan guru kepada siswa. Sebagai seorang guru juga sebaiknya menggunakan beberapa yang menarik dan mudah dimengerti oleh anak, seperti penggunakan media visual yang maka akan menampilakan beberapa gambar untuk tahap pengenalan materi kepada anak akan terlihat lebih menarik dan anak akan mampu menerima materi yang disampaikan oleh guru.

Menurut pemaparan diatas dapat disimpulkan bahwa penggunaan pendekatan,metode dan media yang bervariasi dan tepat terhadap siswa hiperaktif dapat menyelesaikan beberapa permasalahan yang dialami oleh siswa hiperaktif dalam proses pembelajaran. Maka diharapkan agar pendidik tetap menggunakan serta mengembangkan metode dan media yang sudah digunakan agar siswa hiperaktif mampu menerima materi yang disampaikan dan mampu melakasanakan pembelajaran dengan baik.

\section{c.Melatih konsentrasi siswa dalam pembelajaran}

Melatih konsentrasi siswa hiperaktif sangatlah tidak mudah karena siswa hiperkatif sendiri adalah siswa yang tidak bisa tenang, sulit mengontrol emosi, bertindak semaunya sendiri tanpa menghiraukan keberadaan orang lain di sekeliling nya. Oleh karena itu guru harus memiliki cara khusus untuk melatih konsentrasi siswa seperti menggunakan tempat duduk khusus untuk anak hiperaktif agar bisa tekendalikan selama proses pembelajaran dan menggunakan beberapa bujukan untuk memotivasi siswa agar mau melaksanakan proses pembelajaran dengan baik.

Agar mampu mencapai hal yang diinginkan maka di perlukan nya kerjasama antara guru dengan orang tua peserta didik. Untuk saling bertukar informasi dan cara utnuk menangani siswa hiperaktif dengan baik dan sesuai dengan kebutuhan siswa. Begitu pula saat di sekolah, siswa diberikan bimbingan dan penanganan yang baik oleh guru agar siswa tetap merasa nyaman dan aman ketika proses pembelajaran berlangsung.

Bedasarkan hasil wawancara dengan guru khusus yang menyatakan bahwa:

"Untuk melatih konsentrasi siswa guru melakukan berbagai cara untuk mengantur ketenangan emosi siswa,setelah siswa tenang maka akan lebih mudah untuk melatih konsentrasi siswa pada saat proses pembelajaran berlangsung. Dengan cara menyediakan tempat duduk khusus (kursi khusus) untuk siswa hiperaktif. Hal ini bertujuan untuk mengatur siswa untuk tetap diam di tempatnya, karena siswa hiperaktif adalah siswa yang sulit diam, banyak bergerak dan cepat bosan". (W/G2/F1.e/05/09/2019)

Hal ini dikuatkan oleh guru khusus yang mengatakan:

"Bahwa siswa hiperaktif adalah anak yang banyak bergerak,tidak mau diam ditempat, mudah terganggu dan cepat bosan. Maka guru harus lebih ekstra ketika menghadapi siswa hiperaktif dan harus menggunkan caracara yang menarik untuk tetp mempertahankan konsentrasi nya". (W/G1/F3.a/04/09/2019)

Bedasarkan peryataan guru kelas dan guru khusus hiperaktif di atas Anak hiperaktif yaitu anak yang berprilaku tidak selaras dengan norma-norma dan aturan-aturan yang ditetapkan oleh lingkungan sekolah maupun lingkungan masyarakat. Tingkah laku yang menyimpang dengan norma, menunjukan pada mengganggu teman yang ada disekitarnya.

Cara khusus dalam menangani siswa hiperaktif diperlukannya bimbingan dari seorang guru ketika proses pembelajaran berlangsung, seperti yang telah di katakan pula oleh Guru kelas siswa hiperaktif yang menyatakan bahwa:

"Bahwa bimbingan yang sering diberikan oleh Guru kelas dalam proses pembelajaran yang terpenting adalah ketenangan siswa, karena apabila dari mulai datang ke sekolah siswa sudah tidak tenang maka seterusnya siswa akan bertindak semaunya ketika proses pembelajaran berlangsung, Selain bimbingan pembelajaran guru juga memberikan bimbingan kepada siswa hiperaktif berupa selalu membiasakan siswa untuk bersalaman dengan orang yang lebih tua,sebagai salah satu cara untuk menghormati orang tua". (W/G2/F2.c/05/09/2019)

Bedasarkan wawancara yang peneliti lakukan terhadap Guru kelas dan guru khusus hiperaktif, bahwa pemberian bimbingan dan pengunaan pedekatan yang tepat sangat berpengaruh terhadap kesiapan mental,emosi, dan ketenangan siswa dalam proses pembelajaran di kelas. Maka dengan begitu guru tidak akan mengalami kesulitan dalam memberikan materi dan pembelajaran kepada siswa hiperaktif.

Bimbingan dan penanganan harus sesuai dengan kebutuhan siswa akan mempermudah siswa dalam menerima materi pembelajaran yang disamapikan oleh guru. 


\section{PEMBAHASAN}

\section{Martapura. \\ Permasalahan Proses Pembelajaran Anak Berkebutuhan Khusus Hiperaktif Di SLB Negeri}

Permasalahan yang dialami oleh guru pada saat proses pembelajaran adalah keatifan siswa yang berlebihan, sulit dalam menerima materi yang telah disampaikan oleh guru, serta perilaku dan emsoi yang sulit terkontrol, mengalami kesulitan dalam bersosial dilingkungan masyarakat mau pun berinteraksi dengan teman sebaya nya.

Hal ini pun telah dijelaskan oleh (Baihaqi dan M. Sugiarmi,2006:2) bahwa istilah yang sering muncul pada dunia medis dan belakangan ini pula diperbincangkan dalam dunia pendidikan dan psikologi. Istilah ini memberikan gambaran tentang sesuatu kondisi medis yang disahkan secara internasional mencakup disfungsi otak, dimana individu mengalami kesulitan dalam mengendalikan impuls, menghabat perilaku,dan tidak mendukung rentang perhatian mereka. Jika ini terjadi pada seorang anak dapat menyebabkan berbagai kesulitan belajar, kesulitan berperilaku, kesulitan sosial, dan kesulitan-kesulitan lain yang kait-mengait.

Siswa hiperaktif sering kali bertindak tanpa berfikir dan sulit memusatkan perhatian. Mereka mungkin saja paham apa yang dari dirinya namun sulit untuk melaksanakan hal tersebut, karena merika tidak mau duduk diam, menaruh perhatian, dan menyimak detail-detail yang diperlukan dalam menyelesaikan suatu tugas yang diberikan (Indah Candraningtyas, 2013:2)

Berdasarkan beberapa pendapat diatas disimpulkan bahwa, permasalahan proses pembelajaran yang dialami oleh siswa adala kurangnya konsentrasi, tidak bisa diam, dan bersosial dalam lingkungan masryarakat. Maka diperlukan nya penanganan yang dilakukan guru terhadap siswa hiperaktif ketika proses pembelajaran berlangsung yaitu menggunakan pendekatan yang susai dengan keadaan dan kondisi ketenangan siswa pada saat awal masuk kelas, lalu menggunakan metode yang tepat agar berlangsungnya proses pembelajaran yang sesuai dengan kebutuhan siswa seperti halnya dengan penggunaan media pembelajaran yang sesuai dengan keingin siswa agar siswa agar mau melaksanakan pembelajaran atau menggunakan media yang menarik seperti media gambar dan media benda nyata. Agar lebih mudah untuk mengatur dan mengkodisikan siswa agar tetap berkonsentrasi dalam belajar.

Hal ini dilakukan agar siswa mampu menerima pembelajaran dengan baik dan guru tidak menemukan masalah yang sama ketika proses pembelajaran berlangsung. Berdasarkan hasil wawancara yang Peneliti lakukan kepada guru kelas dan guru khusus hiperaktif di SLB Negeri Martapura.

Berdasarkan pemaparan data di atas melalui observasi dan wawancara, bahwasanya seorang guru memiliki beberapa metode yang digunakan untuk menangani dan mengatasi permasalahan siswa hiperaktif. Maka diharapkan Pendidik tetap mempertahankan berbagai macam pendekatan,metode dan media yang telah digunakan sebelumnya, karena pendeketan, metode dan media tersebut telah memberikan dampak positif terhadap kemampuan siswa dalam mengontrol diri,ketenangan dan semangat belajar bagi siswa. Namun, akan lebih baik jika guru memiliki metode dan media baru yang dapat di kembangkan agar terlihat lebih menarik dan membuat siswa lebih semangat dan termotivasi dalam melaksanakan pendidikan dan kehidupan yang akan datang. 


\section{a. Pemberian Motivasi}

Pemberian motivasi yang diberikan guru untuk siswa berkebutuhan khusus hiperaktif, sangatlah penting untuk siswa melaksanakan pendidikan serta mengembangkan prestasi non-akademik yang dimiliki oleh anak. Prestasi non-akademik yang dimiliki anak dapat di salurkan melalui pontesi dan bakat anak, seperti mengikut sertakan anak dalam lomba yang di adakan sesuai dengan bakat yang dimiliki anak.

Menumbuhkan motivasi pada siswa yang mengalami kesulitan belajar serta tidak memili semangat untuk melaksanakan pendidikan dan kehidupan yang akan datang. Dalam hal ini dapat dikatakan bahwa sangat besar pengaruhnya bagi Guru khusus dan guru kelas hiperaktif untuk mengetahui perkembangan siswanya.

Guru sebagai ujung tombak dalam pendidikan yaitu "digugu" dan "ditiru" dalam meningkatkan motivasi siswa, maka seorang Guru khususnya Guru khusus hiperaktif juga harus mampu memotivasi dirinya, menjadi teladan yang baik karena segala perbuatannya selalu menjadi sorotan bagi siswanya.

Berdasarkan hasil observasi, wawancara dan dokumentasi yang telah dijelaskan dalam data di atas tentang permaslahan proses pembelajaran siswa hiperaktif, meliputi pendekatan, bujukam, dan menumbuhkan semangat belajar siswa. Maka dapat dipahami bahwa pemberian motivasi, penanganan, pendekatan, metode dan media sangat efisien untuk siswa hiperaktif, jika Guru selalu meningkatkan motivasi, pendekatan, metode dan media yang digunakan kepada siswa untuk melaksakan pembelajaran maka siswa akan selalu bersemangat dalam melaksanakan pembelajaran meskipun terkadang tingkat ketenangan dan emosi siswa tidak setabil dan terdapat kesulitan serta kendala yang dialami guru dan siswa.

\section{b. Pemberian Bimbingan Dan Penggunaan Pendekatan, Metode Dan Media Pembelajaran}

Bimbingan yang digunakan Guru Khusus Hiperaktif dalam menangani dan mengatasi permasalahan pembelajaran yang ada pada siswa hiperaktif melalui bimbingan dalam melaksanakan pembelajaran yang efektif dan menyenangkan, digunakan agar siswa dapat menerima materi dengan baik dan melangsungkan kehidupan yang akan datang. Adapun bimbingan yang diberikan oleh guru khusus hiperaktif yaitu membimbing Siswa dalam melaksakan proses pembelajaran dikelas dengan cara di kenal dengan beberapa media benda kongkrit yang sudah disediakan oleh guru.

Selain bimbingan penggunaan pendekatan dan metode yang digunakan guru juga sangat berpengaruh terhadap kesiapan siswa dalam melaksanakan pendidikan, mengatur tingkah laku siswa serta kebiasaan yang sering dilakukan oleh siswa hiperaktif. Agar tercipta pembelajaran yang efektif dan menyenangkan di perlukan juga media yang tepat dan sesuai dengan kebutuhan anak, seperti media gambar, media benda kongkrit dan media lansung.

Menurut Sutikno (2014: 33-34) metode diartikan sebagai suatu cara atau prosedur yang dipakai untuk mencapai tujuan tertentu. Kata "pembelajaran" berarti segala upaya yang dilakukan oleh pendidik agar terjadi proses belajar pada diri peserta didik. Jadi metode pembelajaran adalah cara-cara menyajikan materi pelajaran yang dilakukan oleh pendidik agar terjadi proses belajar pada peserta didik dalam upaya untuk mencapai tujuan.

Media adalah kata jamak dari "medium" yang mempunyai arti perantara atau pengantar. Kata media berlaku untuk berbagai suatu pekerjaan atau kegiatan seperti seuatu media dalam penyampaian pesan, istilah ini juga dipakai dalam ilmu pengajaran seperti media pendidikan atau media pembelajaran.(Wina Sanjaya,2013:163)

Berdasarkan penyajian di atas melalui observasi dan wawancara, menunjukan bahwa pemberian bimbingan dan pendekatan serta metode kepada Siswa hiperaktif sangat mempengaruhi keberhasilan Siswa dalam melaksanakan pembelajaran serta memperbaiki kebiasaan dan tingkah laku siswa hiperaktif. Melalui bimbingan Siswa akan lebih terkontrol dalam menghadapi hal dan sitiuasi apapun. Dan orangtua akan lebih mudah dalam mengawasi anak hiperktif selama di lingkungan keluarga dan masryakat dengan adanya bimbingan dari guru khusus hiperaktif, siswa akan dapat mengetahui arti pendidikan dan kehidupan yang dijalani.

\section{SIMPULAN}

Berdasarkan penelitian yang telah dilaksanakan oeleh Penulis dengan judul "Permasalahan Proses Pembelajaran Anak Berkebutuhan Khusus Hiperaktif Kabupaten OKU Timur Tahun Pelajaran 2019/2020 ". Melalui hasil observasi, wawancara dan dokumentasi maka dapat disimpulkan bahwa: Penanganan guru dalam prose pembelajaran pada anak hiperaktif ialah dilakukan a) pemberian motivasi melalui proses pendeketan kepada siswa hiperaktif untuk melatih emosional siswa, b) penggunaan metode-metode yang inovatif yang sesuai dengan kebutuhan siswa dan menarik agar siswa mau melaksanakan pembelajaran dengan baik dan menyenangkan, c) menggunakan media-media yang menarik dan terlihat, seperti media benda kongkrit dan media gambar yang terlihat nyata. Agar siswa mampu menerima dan memahami materi dengan baik karena anak hiperaktif cenderung sulit untuk melaksakan pembelajaran, sulit memahami materi yang disampaikan, dan sulit untuk menghafal. Dengan digunakan media yang nyata maka akan lebih menarik minat siswa untuk belajar dan mempermudah guru dalam menangani dan melatih konsentrasi siswa hiperaktif. 
Terlaksananya proses pembelajaran yang baik pada anak hiperaktif tidak lepas dari kerjasama anatara pihak sekolah dengan orang tua siswa dan penggunaan metode dan media yang tepat serta menarik dalam proses pembelajaran. Sehingga dapat memfokuskan untuk lebih berkonsentrasi pada materi yang disampaikan oleh guru, siswa juga lebih mudah memahami apa yang disampaikan oleh pendidik.

Faktor pendukung dalam pelaksanaan proses pembelajaran pada anak berkebutuhan khusus hiperaktif, yaitu: dukungan orangtua, bimbingan guru khusus dan guru kelas hiperaktif dan sarana prasarana yang memadai.

Faktor penghambat dalam pelaksanaan proses pembelajaran pada anak berkebutuhan khusus hiperaktif, yaitu berdasarkan hasil observasi dan wawancara yang dilakukan peneliti dilapangan seperti: a) lingkungan sosial yang tidak mampu menerima keadaan dan gangguan yang ada pada anak berkebutuhan khusus b) kebiasaan tingkah laku dan emosional siswa yang cenderung memiliki tingkat emosional yang tinggi dan tidak bisa diam.

\section{UCAPAN TERIMAKASIH}

1. Ayahanda dan Ibunda tercinta yang telah memberikan dorongan baik dari segi moril, materil, dan spiritual, semoga pengorbanannya, kasih sayangnya mendapat imbalan yang sebesar-besarnya disisi Allah SWT.

2. Bapak H. Imam Rodin, M.Pd. selaku ketua STKIP Nurul Huda Sukaraja atas segala motivasi, bimbingan dan layanan fasilitas yang telah diberikan selama penulis menempuh studi.

3. Bapak Ahmad Taufiq Yuliantoro, M.Pd. sebagai Ketua Program Studi Pendidikan Guru Madrasah Ibtidaiyah STKIP Nurul Huda Sukaraja sekaligus sebagai pembimbing utama penulisan skripsi ini yang tiada henti memotivasi, memberikan masukan, nasihat, dan bimbingan dengan penuh kesabaran.

4. Ratih Purnama Pertiwi, M.Pd. Sebagai pembimbing I penyusunan skripsi ini yang telah mencurahkan tenaga dan waktunya untuk membimbing dalam penulisan skripsi ini.

5. Bapak Ahmad Ulin Ni'am, M.Pd.I sebagai pembimbing II yang telah memberikan berbagai masukan, pembenaran, bimbingan, arahan dan terus memberikan motivasi terbaiknya.

6. Bapak dan ibu dosen serta segenap staf STKIP Nurul Huda Sukaraja yang telah banyak membantu dan memberikan ilmu pengetahuan kepada penulis.

7. Kepala Sekolah SLB Negeri Martapura, yang telah memberikan ijin dan bantuan dalam pelaksanaan penelitian Tugas Akhir Skripsi ini.

8. Para Guru dan staf SLB Negeri Martapura, yang telah memberi bantuan memperlancar pengambilan data selama proses penelitian Tugas Akhir Skripsi ini.

9. Teman-teman seperjuangan program studi pendidikan guru madrasah ibtidaiyah serta semua pihak yang tidak dapat penulis sebutkan satu persatu yang telah membantu penulis dalam menyelesaikan Tugas Akhir Skripsi ini.

\section{DAFTAR PUSTAKA}

Aan Komariah dan Djam'an Satori. Metodologi Penelitian Kualitatif. Bandung; Alfabeta, 2014.

Amalia Sapriati,dkk. Metode Pembelajaran. Universitas Terbuka,2010.

Arikunto, Suharsini. 2006. Prosedur Penelitian Suatu Pendekatan Praktik Jakarta: Rineka Putra.

Damayanti, P.A. 2015. Sekolah Dasar Luar Biasa (SDLB).Semarang. Canopy : Journal Of Architecture,4 (2).

Denny Setiawan. Metode Dan media pembelajaran SD. Jakarta: Universitas Terbuka,2010.

Frieda Mangunso. Psikologi dan Pendidikan Anak Berkebuhan Khusus.Jakarta: Universitas Indonesia,2010.

Hamalik, Oemar. 2004. Proses Belajar Mengajar. Jakarta: Bumi Aksara.

Jati Rinakri Atmaja. Pendidikan Dan Bimbingan Anak Berkebutuhan Khusus. Bandung : PT REMAJA

ROSDAKARYA,2018.

Moleong, Lexy J. 2002. Metodologi Penelitian Kualitatif. Bandung: Rosdakarya.

Nur'aeni. 2017. Buku Ajar Psikologi Pendidikan Anak BERKEBUTUHAN .Khusus.Purwokerto:UM Purwoketo Press.

Sugiyono. 2010. Metode Penelitian Pendidikan. Bandung: Alfabeta. 
47 Jemari: Jurnal Edukasi Madrasah Ibtidaiyah, Vol. 2 No. 1, Halaman: 40 - 47, January, 2020

Sukma dinata, Nana Syaodih. 2010. Metode Penelitian Pendidikan. Bandung: Remaja Rosdakarya.

Suryabrata, Sumadi. 2013. Metodologi Penelitian. Jakarta: Rajawali Pers.

Suyanto . 2010. Prosedur Penelitian. Jakarta: Rineka Cipta.

Tentama, F. 2009. Peran orangtua dan guru dalam menangani perilaku hiperaktifitas pada anak ADHD di SLB Negeri 3 Yogyakarta. Jurnal Kesmas,3(1),51-57.

Zuhairi, et.al. 2016. Pedoman Karya Ilmiah. Jakarta: Rajawali Pers. https://almanhaj.or.id diunduh pada 18 agustus 2019 